\title{
Chapter 8 \\ Initiatives by the Soil Fertilization Team to Develop Agricultural Technologies \\ for Paddy Fields with Radioactive \\ Contamination
}

\author{
Itsuo Goto and Kaisei Inagaki
}

\begin{abstract}
In April 2012, the paddy field located $20.8 \mathrm{~km}$ from the Fukushima Daiichi Nuclear Power Station was divided into six plots to apply zeolite and potassium chloride, and a cultivation test of rice was carried out. The concentration of radiocesium in the brown rice was highest in the control plot at $17 \mathrm{~Bq} / \mathrm{kg}$, but in plots where zeolite and potassium fertilizer were applied, the concentrations had decreased to $5-6 \mathrm{~Bq} / \mathrm{kg}$. The efficacy of zeolite efficacy in inhibiting the absorption of radiocesium by rice plants is considered to be mainly the result of its ability to adsorb ammonium and potassium ions, thereby inhibiting the leaching and outflow of nitrogen and potassium from the plow layer.
\end{abstract}

Keywords Radioactive contamination of farmlands $\bullet$ Radiocesium $\bullet$ Zeolite $\bullet$ Rice plant

\subsection{Countermeasure for the Amelioration of Paddy Fields with Radioactive Contamination Jointly with Minamisoma Farmers}

\subsubsection{Radioactive Concentration of Paddy Field on Which a Test Planting of Rice Was Carried Out}

We measured radioactive concentration in plow layer samples (at $15 \mathrm{~cm}$ ) taken from a paddy field located in the city of Minamisoma, $20.8 \mathrm{~km}$ from the Fukushima Daiichi Nuclear Power Station, and the total radiocesium concentration was

\footnotetext{
I. Goto $(\bowtie) \cdot$ K. Inagaki

Department of Applied Biology and Chemistry, Tokyo University of Agriculture,

1-1-1 Sakuragaoka, Setagaya-ku, Tokyo 156-8502, Japan

e-mail: igoto@nodai.ac.jp
} 


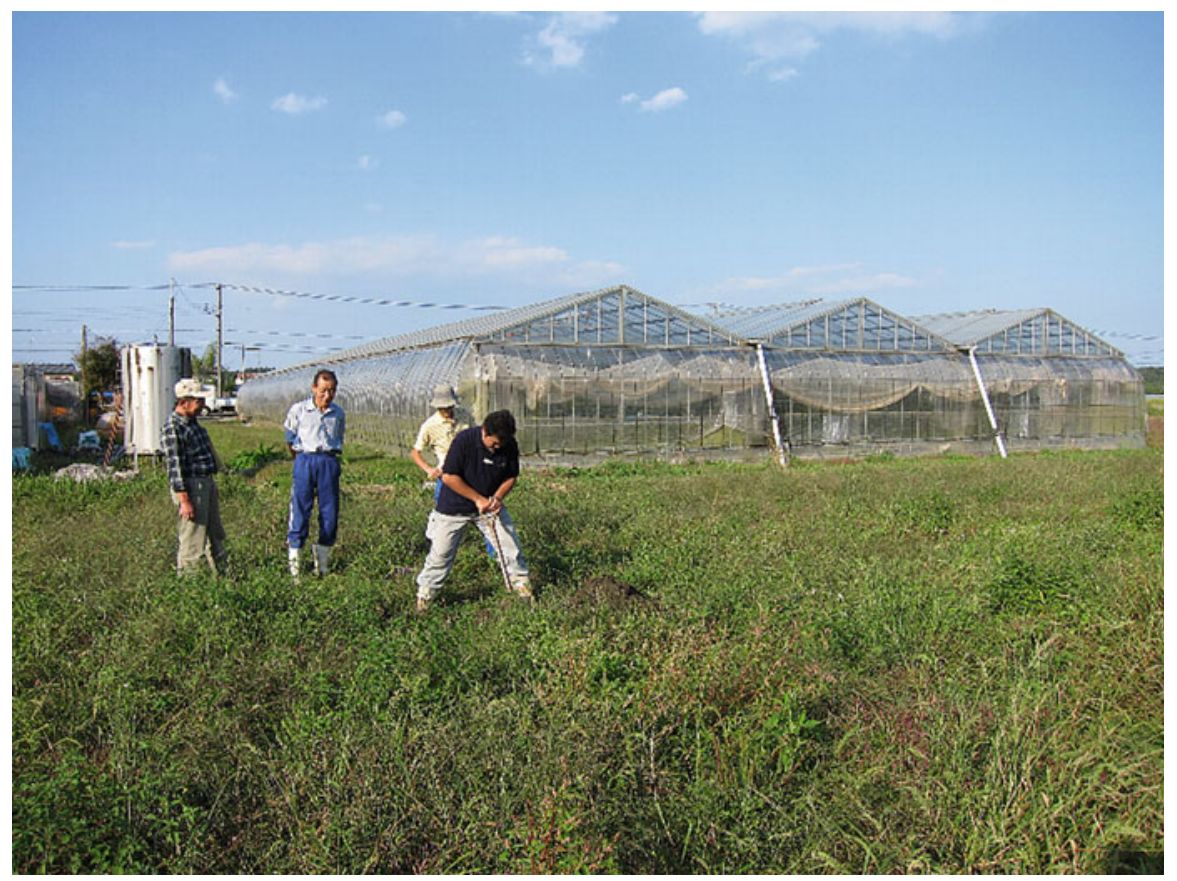

Fig. 8.1 Radioactively contaminated paddy field on which was carried out the rice planting test on Minamisoma City, Fukushima Prefecture (October 2011)

approximately $2,600 \mathrm{~Bq} / \mathrm{kg}$, comprising $1,137 \mathrm{~Bq} / \mathrm{kg}$ of ${ }^{134} \mathrm{Cs}$ and $1,428 \mathrm{~Bq} / \mathrm{kg}$ of ${ }^{137}$ Cs (Fig. 8.1).

In April 2011, the Ministry of Agriculture, Forestry and Fisheries prohibited any rice planting for consumption purposes that year in paddy fields with a radiocesium concentration of $5,000 \mathrm{~Bq} / \mathrm{kg}$ or more in the plow layer, or within a $30-\mathrm{km}$ radius of the nuclear power station. The farmer was unable to plant this paddy field for the latter reason, and it turned into a field full of weeds.

As of October 2011, it was still unclear whether rice planting would be allowed in Minamisoma during 2012. However, we decided to take steps to inhibit the absorption of radiocesium by rice in this paddy field, in line with the farmer's wishes.

\subsubsection{Application of Zeolite, Layer Mixing, and Soil Reversion}

In December 2011, we applied zeolite and mixed the soil layers in the paddy field (Fig. 8.2). We divided 30 ares of the paddy field into three plots to which we applied either 10 or 20 t/ha of zeolite, or no zeolite (the control plot). The natural zeolite we 

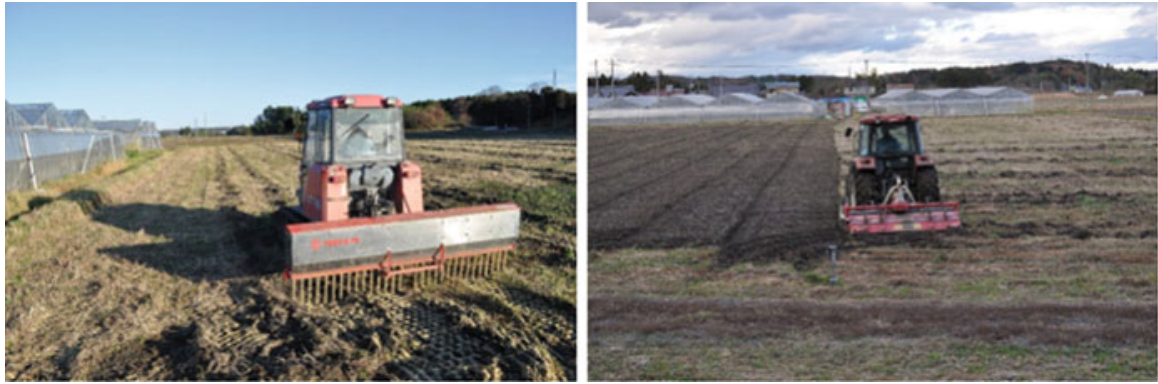

Fig. 8.2 Application of zeolite into paddy field (left photograph) and plow layer with mixing tillage (right photograph) (December 2011)

used for the test was produced by the Iizaka mine of Nitto Funka Kogyo, Co., Ltd. in Koori, Fukushima Prefecture. It had a cation-exchange capacity (CEC) of approximately $150 \mathrm{mEq} / 100 \mathrm{~g}$ with mordenite as its main component.

\subsubsection{Test Planting of Rice}

\subsubsection{Application of Zeolite and Potassium Fertilizer to Inhibit Absorption of Radiocesium}

In April 2012, these paddy fields were divided into six plots to apply zeolite and potassium chloride in different combinations of concentrations: three plots with a standard level of potassium chloride (equivalent to $50 \mathrm{~kg} / \mathrm{ha}$ as $\mathrm{K}_{2} \mathrm{O}$ ) combined with either 0,10 , or $20 \mathrm{t} /$ ha of zeolite, and three plots with a high level of potassium chloride (equivalent to $50+200=300 \mathrm{~kg} / \mathrm{ha}$ as $\mathrm{K}_{2} \mathrm{O}$ ) combined with either 0 , 10 , or $20 \mathrm{t} / \mathrm{ha}$ of zeolite.

In all test plots we applied a combination of legally registered fertilizers $(50 \mathrm{~kg} /$ ha nitrogen, $40 \mathrm{~kg} / \mathrm{ha}$ phosphate, and $50 \mathrm{~kg} / \mathrm{ha}$ potassium), and for the high-potassium test plots, we added extra potassium chloride equivalent to $250 \mathrm{~kg} / \mathrm{ha}$ as $\mathrm{K}_{2} \mathrm{O}$. On May 20, we planted rice of the Hitomebore variety in the paddy field.

It has already been established that the absorption of radiocesium can be inhibited by application of potassium fertilizer in the soil to promote the absorption of potassium by plants, because cesium exhibits the same behavior as potassium, which belongs to the same family of elements. Research to date indicates that radiocesium absorption by rice can be inhibited if the soil contains $25 \mathrm{mg} / 100 \mathrm{~g}$ of exchangeable potassium $\left(\mathrm{K}_{2} \mathrm{O}\right)$ or more. Table 8.1 shows the levels of exchangeable potassium measured in plow layer samples taken while the rice was growing in June, July, and August. Exchangeable potassium amounted to $18 \mathrm{mg} / 100 \mathrm{~g}$ in the standard-potassium $(50 \mathrm{~kg} / \mathrm{ha})$ no-zeolite $(0 \mathrm{t} / \mathrm{ha})$ plot in June, but it exceeded $25 \mathrm{mg} / 100 \mathrm{~g}$ in the other test plots. The reason why the standard potassium plots with zeolite also witnessed an increase in exchangeable potassium was because 
Table 8.1 Temporal changes of exchangeable potassium $\left(\mathrm{K}_{2} \mathrm{O}\right)$ in plow layer soil taken while the rice was growing in June, July, and August

\begin{tabular}{l|l|l|l|l}
\hline \multicolumn{2}{l}{ Plots } & \multicolumn{4}{l}{ Exchangeable $\mathrm{K}_{2} \mathrm{O}(\mathrm{mg} / 100 \mathrm{~g})$} & \\
\hline Zeolite $(\mathrm{t} / \mathrm{ha})$ & $\mathrm{K}_{2} \mathrm{O}(\mathrm{kg} / \mathrm{ha})$ & June & July & August \\
\hline 0 & 50 & 18 & 11 & 18 \\
\hline 0 & 300 & 26 & 22 & 16 \\
\hline 10 & 50 & 28 & 20 & 15 \\
\hline 10 & 300 & 40 & 26 & 17 \\
\hline 20 & 50 & 43 & 23 & 18 \\
\hline 20 & 300 & 43 & 37 & 25 \\
\hline
\end{tabular}

Table 8.2 Radiocesium concentration in rice straw of the panicle formation stage and brown rice

\begin{tabular}{l|c|c|c|l|l|l|r}
\hline \multicolumn{4}{l}{ Plots } & \multicolumn{3}{l}{ Straw $(\mathrm{Bq} / \mathrm{kg})$} & \multicolumn{3}{l}{ Brown rice $(\mathrm{Bq} / \mathrm{kg})$} \\
\hline Zeolite $(\mathrm{t} / \mathrm{ha})$ & $\mathrm{K}_{2} \mathrm{O}(\mathrm{kg} / \mathrm{ha})$ & ${ }^{134} \mathrm{Cs}$ & ${ }^{137} \mathrm{Cs}$ & Total & ${ }^{134} \mathrm{Cs}$ & ${ }^{137} \mathrm{Cs}$ & Total \\
\hline 0 & 50 & 24.4 & 37.6 & 62.0 & 6.1 & 10.5 & 16.6 \\
\hline 0 & 300 & 7.6 & 12.4 & 20.0 & 2.5 & 3.9 & 6.4 \\
\hline 10 & 50 & 14.2 & 20.4 & 34.6 & 4.5 & 7.3 & 11.8 \\
\hline 10 & 300 & 7.8 & 12.2 & 20.0 & 2.4 & 3.6 & 6.0 \\
\hline 20 & 50 & 7.6 & 12.7 & 20.3 & 2.4 & 3.9 & 6.3 \\
\hline 20 & 300 & 6.7 & 9.1 & 15.8 & 2.0 & 3.3 & 5.3 \\
\hline
\end{tabular}

Measuring equipment: germanium detector

Detection limit

Straw: $10 \mathrm{~Bq} / \mathrm{kg}$ (12-h measurement with U8 container)

Brown rice: $5 \mathrm{~Bq} / \mathrm{kg}$ (80-min measurement with the marinade re-container of $2 \mathrm{l}$ )

zeolite contains exchangeable potassium. Subsequently, as the rice grew, the amount of exchangeable potassium in all the test plots decreased, reaching about $15-25 \mathrm{mg} / 100 \mathrm{~g}$ in August.

\subsubsection{Radioactive Concentration of Rice (Brown Rice and Straw)}

Table 8.2 shows the concentration of radiocesium in the rice straw (stems and leaves of the panicle formation stage) sampling in July (Fig. 8.3), as well as the harvested brown rice, in September 2012. The concentration of radiocesium in the brown rice was highest in the standard-potassium, no-zeolite plot at $17 \mathrm{~Bq} / \mathrm{kg}$, but in plots where zeolite and potassium fertilizer were applied, the concentrations had decreased to 5-6 Bq/ $\mathrm{kg}$. The radiocesium detected in the rice straw sampled in July and August was three times the concentration found in the brown rice sampled at the same time. However, as with the brown rice, the concentrations of radiocesium in straw from the plots applied with both zeolite and potassium fertilizers were lower than in straw from the plots without zeolite. The detection limits were approximately $10 \mathrm{~Bq} / \mathrm{kg}$ for the rice straw and approximately $5 \mathrm{~Bq} / \mathrm{kg}$ for the brown rice, 


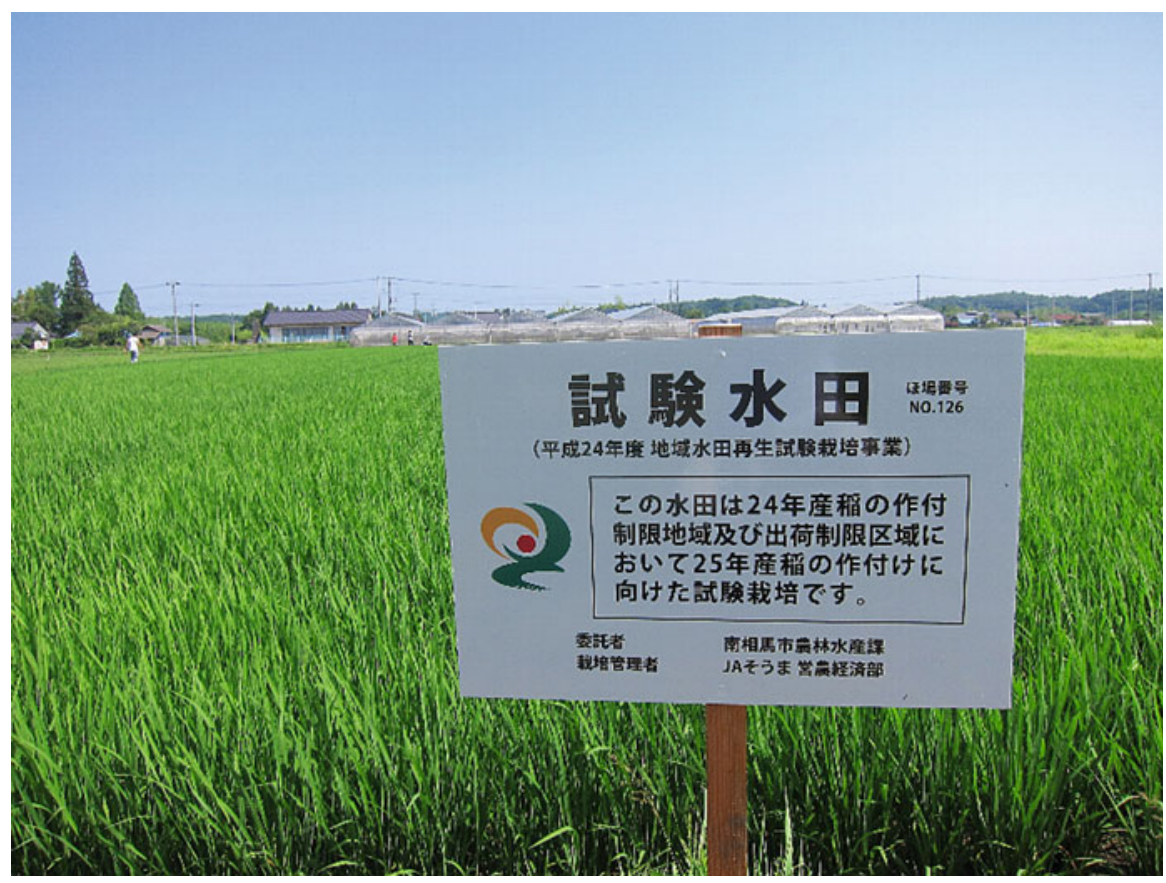

Fig. 8.3 Rice of the panicle formation stage in paddy field of the rice planting test (July 2012)

and the quantification limits were about three times higher. The only test plot in which the concentrations of radiocesium exceeded the quantification limits was the standard-potassium, no-zeolite plot. Because the concentrations in all the other test plots were below these limits, it was impossible to compare the measurements quantitatively. However, it was clear that the application of a potassium fertilizer, or zeolite, or a combination of these materials, was effective in inhibiting the absorption of radiocesium. Nevertheless, zeolite efficacy in reducing radiocesium content when applied alone or together with a potassium fertilizer, and the mechanism by which it does so, were still not clearly known.

\subsubsection{Investigating the Mechanism of Zeolite from the Yield and Taste Rating of Brown Rice}

Table 8.3 shows the yield of brown rice together with taste appraisal values taken by a rice taste analyzer (Shizuoka Seiki PS-500). As shown in Fig. 8.4, the rice yield increased with the application of zeolite and potassium fertilizers. In addition, the protein content increased as the yield increased, and a high level of correlation is observed between the two, as shown in Fig. 8.5. Upon analyzing the factors causing the increase in protein content, we found no increase in protein content resulting 
Table 8.3 Yield of brown rice and taste appraisal values taken by rice taste analyzer ${ }^{\mathrm{a}}$

\begin{tabular}{|c|c|c|c|c|c|c|c|}
\hline \multicolumn{2}{|l|}{ Plots } & Yield & \multicolumn{5}{|c|}{ Taste appraisal values } \\
\hline Zeolite & $\mathrm{K}_{2} \mathrm{O}$ & & Moisture & Protein & Amylose & Fatty acid & \\
\hline t/ha & $\mathrm{kg} / \mathrm{ha}$ & $\mathrm{t} / \mathrm{ha}$ & $\%$ & $\%$ & $\%$ & $\mathrm{mg} / 100 \mathrm{~g}$ & Score \\
\hline 0 & 50 & 4.49 & 15.8 & 6.0 & 19.8 & 13.3 & 78.7 \\
\hline 0 & 300 & 4.93 & 15.5 & 6.1 & 19.9 & 13.7 & 76.7 \\
\hline 10 & 50 & 5.30 & 16.0 & 6.4 & 20.2 & 14.7 & 73.7 \\
\hline 10 & 300 & 6.09 & 16.3 & 6.4 & 20.0 & 15 & 73 \\
\hline 20 & 50 & 5.53 & 15.9 & 6.2 & 19.9 & 14 & 76.7 \\
\hline 20 & 300 & 6.76 & 16.3 & 6.5 & 19.8 & 15.3 & 72.3 \\
\hline
\end{tabular}

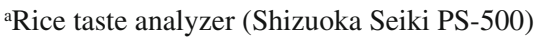
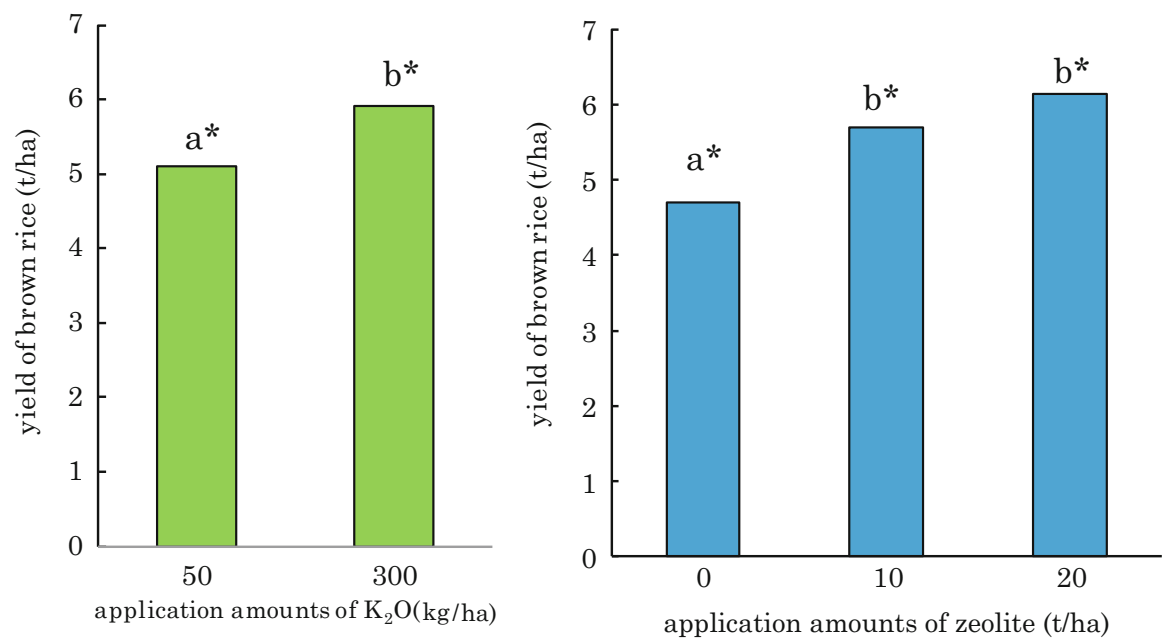

Fig. 8.4 Effects of zeolite or potassium application on yield of brown rice. *Different letters indicate significant differences (Tukey's $q$ test, $p<0.25$ )

from the application of potassium (as shown in Fig. 8.6), but we found that the protein content tended to rise with the application of zeolite. It is well known that the taste appraisal values of brown rice drops if the protein content increases and a significant correlation between the taste appraisal values and protein content was observed in this test as well. When the factors behind the drop in taste rating were analyzed, the results showed that the rating tended to drop with the application of zeolite, as shown in Fig. 8.7.

These results indicated that the application of zeolite promoted the absorption of nitrogen fertilizer in the rice plants, bringing about an increase in the protein content and yield of the brown rice. It was considered that the increased efficiency of nitrogen fertilizer application resulting from zeolite could be related to the inhibition of radiocesium absorption. 
8 Initiatives by the Soil Fertilization Team to Develop Agricultural Technologies...

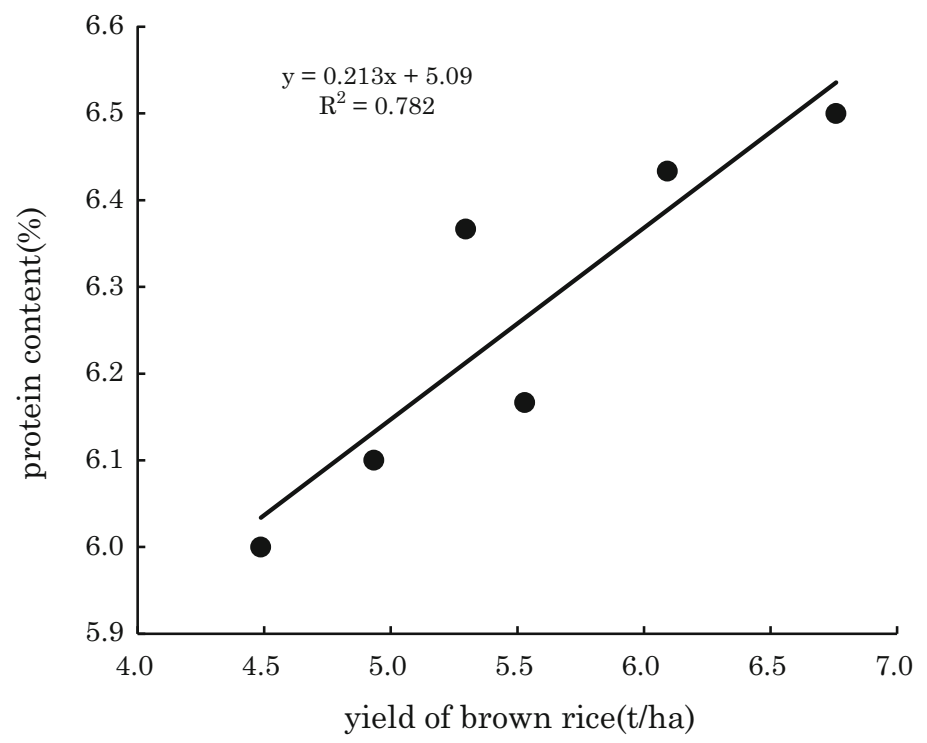

Fig. 8.5 Relationship between yield and protein content of brown rice

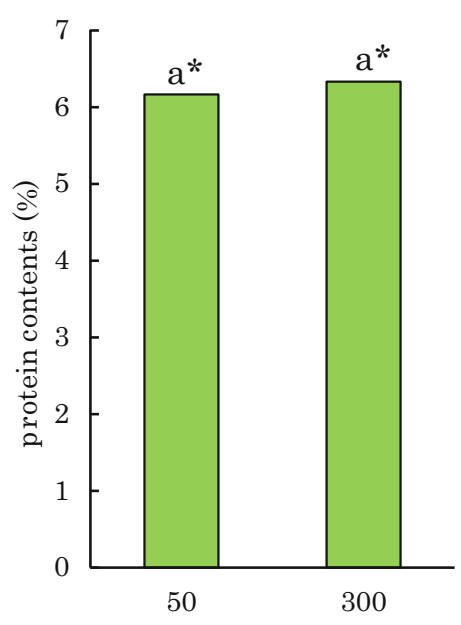

application amounts of $\mathrm{K}_{2} \mathrm{O}(\mathrm{kg} / \mathrm{ha})$

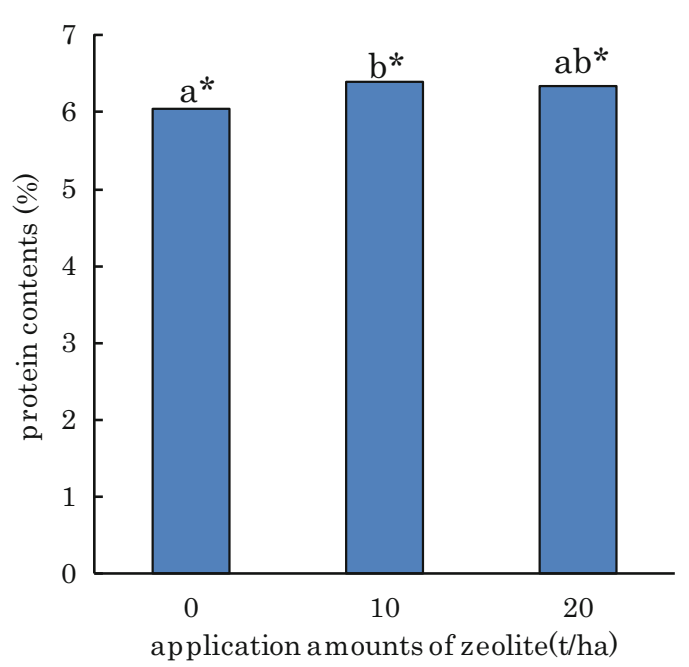

application a mounts of zeolite(t/ha)

Fig. 8.6 Effect of zeolite or potassium application on protein content of brown rice. *Different letters indicate significant differences (Tukey's $q$ test, $p<0.25$ ) 

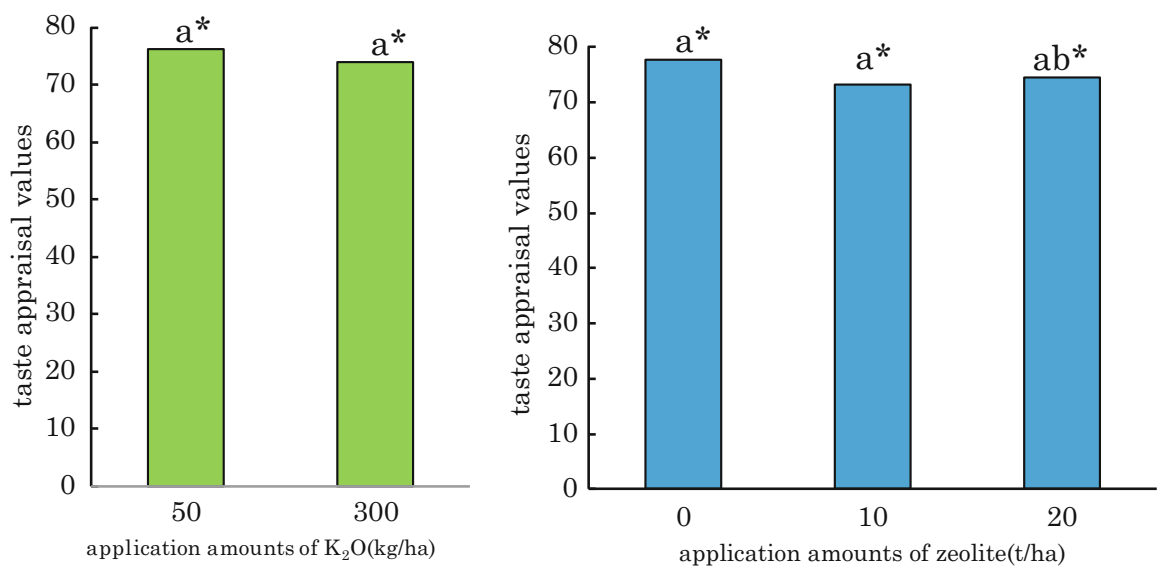

Fig. 8.7 Effects of zeolite or potassium application on taste appraisal values of brown rice. *Different letters indicate significant differences (Tukey's $q$ test, $p<0.25$ )

\subsection{Countermeasure for the Amelioration of Paddy Fields with Radioactive Contamination in Date City}

\subsubsection{Test Planting of Rice in Date}

In the fall of 2011, a large quantity of rice from the mountain paddy fields in the Abukuma Highlands in the city of Date, Fukushima Prefecture, was found to exceed the government's provisional radiation limit of $500 \mathrm{~Bq} / \mathrm{kg}$. As a result, rice planting for consumption purposes was prohibited in six districts within the city in 2012 .

In a tie-up with JA Datemirai, a local agricultural cooperative, we carried out rice planting tests to investigate the application effects of zeolite and potassium fertilizers, or amelioration of soil acidity, on the absorption of radiocesium to rice plants.

\subsubsection{Method of Rice Planting Test}

As shown in Table 8.4, two adjacent plots were set up as test plots in each of three locations (A, B, and C in Fig. 8.8) in the Kakeda district of Ryozen, a town in Date. In Kakeda Paddy A, which had a radiocesium concentration of 7,600 Bq/kg in the plow layer in April 2011, we studied the application effect of zeolite alone. In Kakeda Paddy B, which had a radiocesium concentration of 8,700-10,360 Bq/kg, we compared different combinations of zeolite and two different types of potassium fertilizer (potassium chloride and potassium silicate). In Kakeda Paddy C, which had a radiocesium concentration of $4,900 \mathrm{~Bq} / \mathrm{kg}$, we observed the application effect of converter slag for amelioration of soil acidity. In the middle of May we applied 


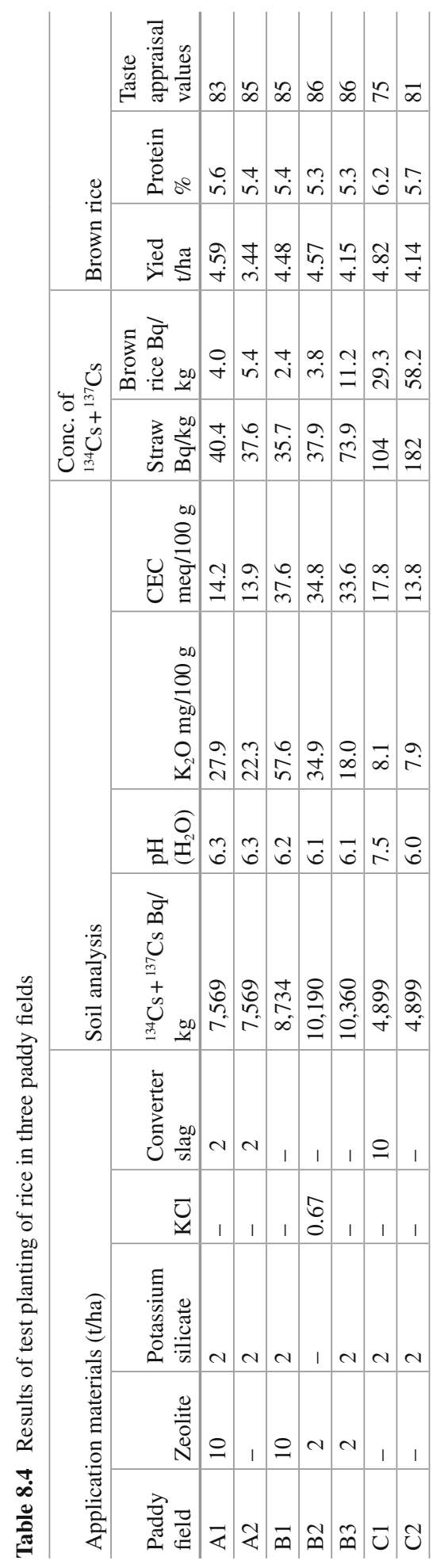



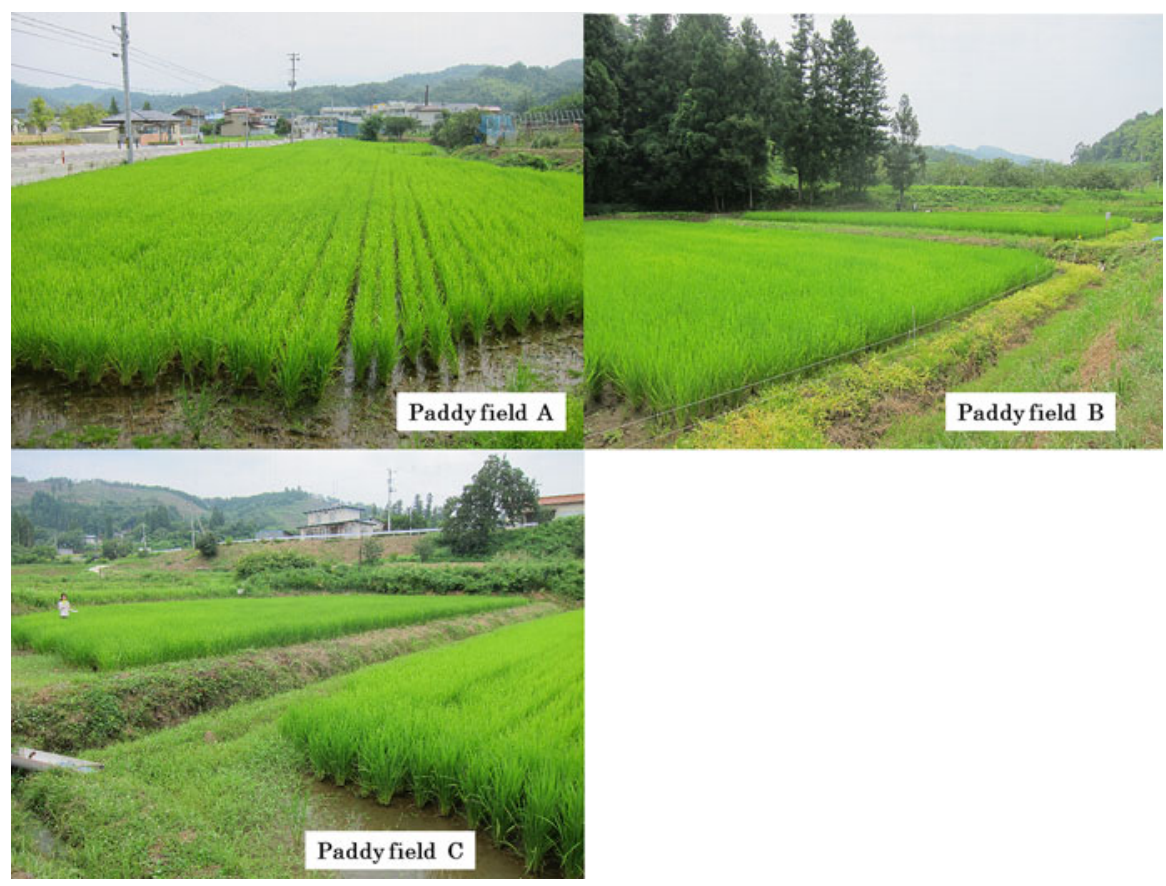

Fig. 8.8 Paddy fields for rice planting test in Date City

the materials to treat the soil and replanted rice of the Koshihikari variety into the paddy fields, harvesting the rice on September.

\subsubsection{Test Results}

As shown in Table 8.4, we observed no changes in radiocesium concentration from the application of $10 \mathrm{t} / \mathrm{ha}$ of zeolite in paddy field A. However, the protein content and rice yield increased while the taste rating dropped. In addition, the water-soluble potassium content of the exchangeable potassium in the soil after applying fertilizer and after harvesting was lower in the plot where zeolite was applied than in the plot without zeolite.

In paddy field $\mathrm{B}$, the protein content and the taste rating in the brown rice were almost the same between the three test plots, but the rice yield was higher in the plot where $10 \mathrm{t} /$ ha rather than $2 \mathrm{t} / \mathrm{ha}$ of zeolite was applied and the plot where potassium chloride was applied. In addition, the radiocesium concentration in the stems and leaves, as well as in the brown rice, dropped in both these plots. Application of zeolite, or potassium chloride as a potassium fertilizer, was effective for inhibition of the radiocesium to rice in this paddy field. 
In paddy field $\mathrm{C}$, the application of $10 \mathrm{t} / \mathrm{ha}$ converter slag resulted in radiocesium concentration in the stems and leaves, as well as in the brown rice, decreasing by approximately half. On the other hand, the protein content in the rice increased, while the yield also increased by $16 \%$. The taste rating dropped in line with these changes.

As shown here, no effect on radiocesium levels from application of zeolite alone was evident in paddy field A. In paddy field B, the application of zeolite and potassium chloride resulted in reduction of the radiocesium concentration in the stems and leaves, as well as in the brown rice, but the mechanism was not evident. Nevertheless, an increase in the protein content and yield was observed with the application of zeolite in both paddy fields A and B. This phenomenon is the same as the test result obtained in Minamisoma, and its mechanism can probably be explained by the increase in efficiency of nitrogen fertilizer resulting from the wellknown property of zeolite for specific adsorption of ammonium ion.

In paddy field $\mathrm{C}$, the $\mathrm{pH}$ of the soil rose from 6.0 to 7.5 with the application of converter slag. It is known that when the soil $\mathrm{pH}$ increases, mineralization of nitrogen is accelerated by the alkali effect. The observed increase in the rice yield could also be caused by this alkali effect. In addition, the reduction in the radiocesium concentration in the brown rice is considered to have been caused by a gradual increase in the ammonium ion concentration in the soil, leading to an inhibition in the absorption of radiocesium by the rice as a result of increased competition with the cesium ions.

\subsection{Is Application of Zeolite to Paddy Fields Effective as a Soil Amendment for Inhibition of Radiocesium Absorption in Rice?}

\subsubsection{Cesium-Specific Adsorption Characteristics by Zeolite}

We added $1 \mathrm{~g}$ zeolite to $100 \mathrm{ml}$ cesium chloride solutions containing 1 , 50, or $100 \mathrm{mg} / \mathrm{l}$ cesium $\left({ }^{133} \mathrm{Cs}\right)$ in $100-\mathrm{ml}$ polyethylene containers and left the solutions to stand for $24 \mathrm{~h}$. Subsequently, the solutions were filtered and the ${ }^{133} \mathrm{Cs}$ in the filtrate measured using a quadrupole ICP mass spectrometer. Similar experiments were also carried out for sodium ions and potassium ions of the same concentration for comparison with the cesium. The zeolite used was a natural zeolite with a particle size of 1-2 $\mathrm{mm}$ that contained mainly clinoptilolite produced by the Itaya mine in Yonezawa, Yamagata Prefecture. The cesium adsorption characteristics of the zeolite were stronger than potassium, which was a homologous element (Table 8.5). Within $24 \mathrm{~h}$, just $1 \mathrm{~g}$ zeolite adsorbed almost all the cesium in $100 \mathrm{ml}$ cesium solution with a concentration of $100 \mathrm{mg} / \mathrm{l}$.

Next, $1 \mathrm{~g}$ zeolite was added to $100 \mathrm{ml}$ cesium chloride solution containing $100 \mathrm{mg} / \mathrm{l}{ }^{133} \mathrm{Cs}$ in a $100-\mathrm{ml}$ polyethylene container and then shaken in a shaker for 5 
Table 8.5 Difference in alkali metals ion adsorption ratio of the zeolite

\begin{tabular}{l|l|l|l|l|l|l}
\hline Alkali ion & \multicolumn{3}{|l|}{ Sodium } & Potassium & Cesium \\
\hline Concentration & $\begin{array}{l}\text { Residual } \\
\text { conc. }\end{array}$ & $\begin{array}{l}\text { Adsorption } \\
\text { ratio }\end{array}$ & $\begin{array}{l}\text { Residual } \\
\text { conc. }\end{array}$ & $\begin{array}{l}\text { Adsorption } \\
\text { ratio }\end{array}$ & $\begin{array}{l}\text { Residual } \\
\text { conc. }\end{array}$ & $\begin{array}{l}\text { Adsorption } \\
\text { ratio }\end{array}$ \\
\hline $\mathrm{mg} / \mathrm{l}$ & $\mathrm{mg} / \mathrm{l}$ & $\%$ & $\mathrm{mg} / \mathrm{l}$ & $\%$ & $\mathrm{mg} / \mathrm{l}$ & $\%$ \\
\hline 1 & 0.54 & 45.8 & 0.25 & 74.9 & 0.00 & 99.7 \\
\hline 50 & 38.7 & 22.5 & 1.72 & 96.6 & 0.02 & 99.9 \\
\hline 100 & 88.1 & 11.9 & 3.82 & 96.2 & 0.06 & 99.9 \\
\hline
\end{tabular}

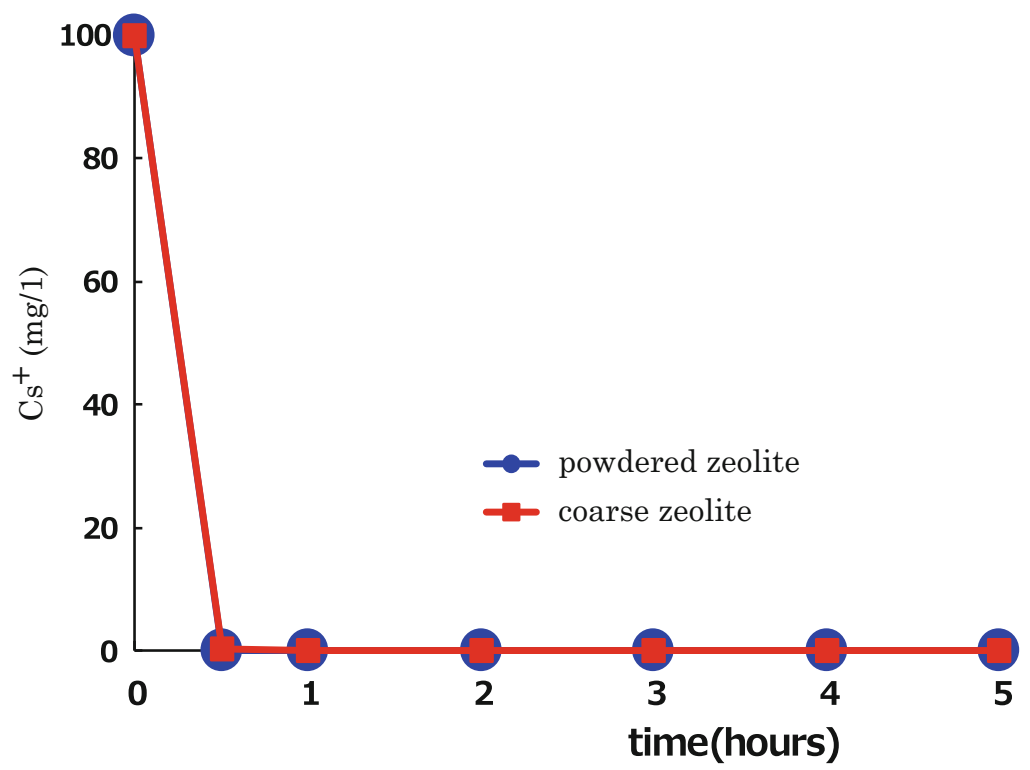

Fig. 8.9 Cesium ion adsorption speed of zeolite

h. After the initial $30 \mathrm{~min}$, the container was taken out of the shaker every hour to be filtered, and then the concentration of ${ }^{133} \mathrm{Cs}$ in the filtrate was measured. Two types of zeolite were used. One was the same coarse zeolite used in the first experiment and the other was the coarse zeolite ground into powder form. As shown in Fig. 8.9, almost all the ${ }^{133} \mathrm{Cs}$ was adsorbed after just $30 \mathrm{~min}$ irrespective of the difference in the zeolite particle size. This result indicated that the zeolite more specifically than potassium adsorbs radiocesium in the radioactively contaminated soil.

Our next aim was to demonstrate the behavior of cesium after it has been adsorbed by zeolite. We obtained three types of natural zeolite produced in different locations in Japan (clinoptilolite from Yamagata Prefecture, mordenite from Fukushima Prefecture, and clinoptilolite from Hokkaido). These three types of zeolite and $0.5 \mathrm{~g}$ each of 22 soils collected from various regions were added individually to $50-\mathrm{ml}$ samples of an aqueous solution containing $1 \mathrm{mg} / \mathrm{l}{ }^{133} \mathrm{Cs}$. The 25 
samples were then shaken for $1 \mathrm{~h}$ before the cesium adsorption ratio was measured. Next, $50 \mathrm{ml} 1 \mathrm{M} / \mathrm{l}$ ammonium acetate with a $\mathrm{pH}$ of 7 was added to these solutions containing zeolite or soil. After shaking for $1 \mathrm{~h}$, the concentration of ${ }^{133} \mathrm{Cs}$ in the filtrate was measured, and then the proportion of cesium that was exchanged and released by the ammonium ions (the release ratio) was calculated. The adsorption ratio of all three types of zeolite was $99.8 \%$ or more (Fig. 8.10). The adsorption ratio for soil was also high, at 94-98\%. However, compared to a release ratio of $26-33 \%$ for zeolite, the release ratio for soils was higher at 48-99\%. In other words, although soils may have an adsorption capability on a par with that of zeolite, zeolite is considered to release less cesium than soils.

As potassium and calcium ions coexist in large quantities in farmland soils, we compared the cesium adsorption properties of zeolite and soil in coexistence with potassium ions. High-humic Andosol sampled from uncultivated land in Kanuma, Tochigi Prefecture; chernozem sampled from wheat fields in Ukraine; and Kanuma pumice were used as the test soils.

We added $0.5 \mathrm{~g}$ zeolite and the aforementioned soils to $50 \mathrm{ml}$ each of two different solutions: a solution containing $1 \mathrm{mg} / \mathrm{l}{ }^{133} \mathrm{Cs}$ only, and an solution containing a mixture of $1 \mathrm{mg} /{ }^{133} \mathrm{Cs}$ and $100 \mathrm{mg} / \mathrm{l} \mathrm{K}$. After shaking for $1 \mathrm{~h}$, the solutions were filtered and the ${ }^{133} \mathrm{Cs}$ measured. As shown in Fig. 8.11, the soils showed a decrease in the cesium adsorption ratio as a result of the coexistence of potassium ions, whereas the zeolite showed no change at all. In other words, zeolite can easily adsorb cesium even in soils with a high concentration of potassium ions, such as cultivated land.

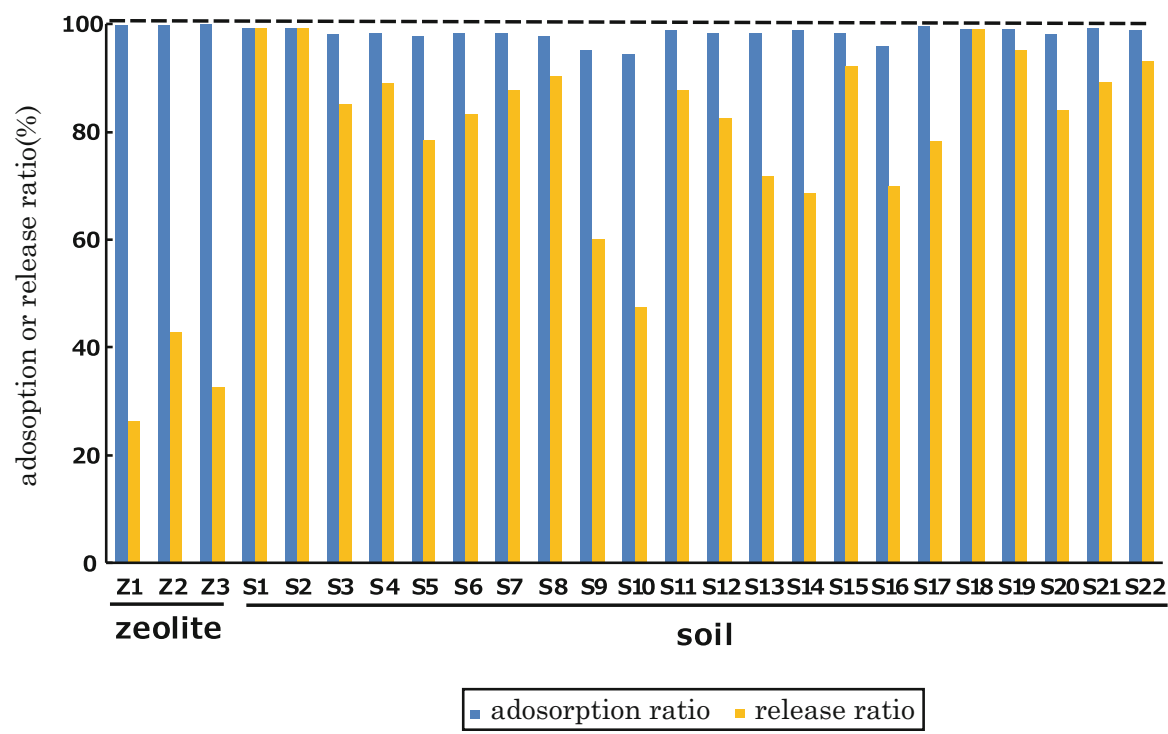

Fig. 8.10 Cesium ion adsorption and release ratio of zeolite and soils 


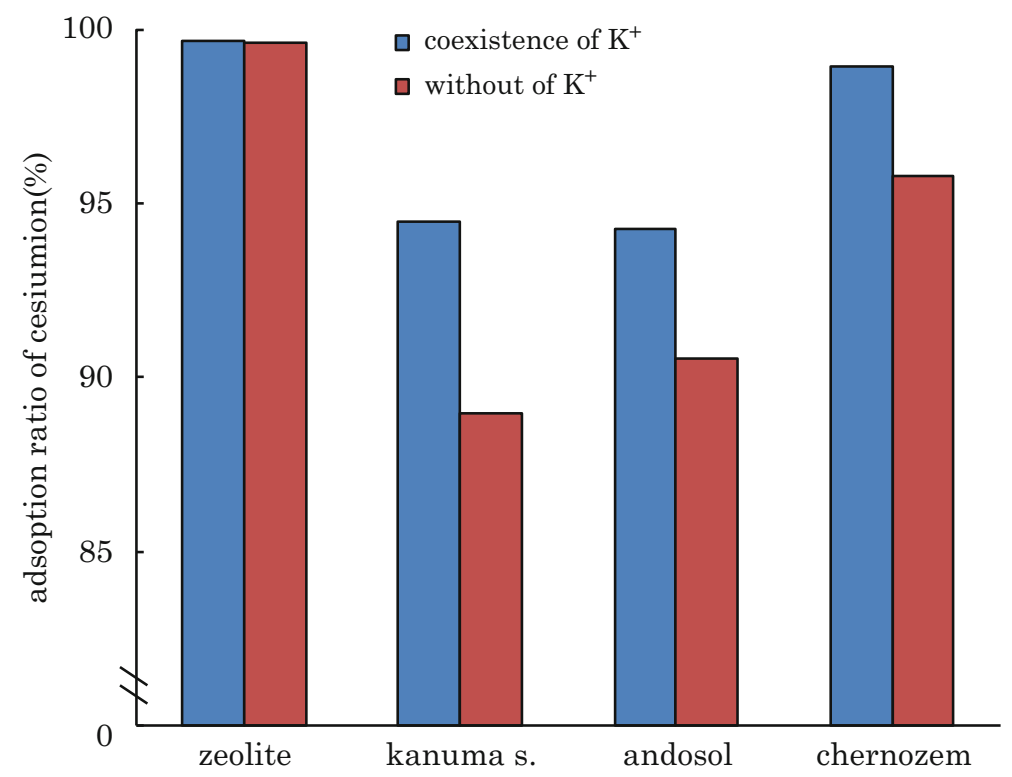

Fig. 8.11 Effects of coexistence of potassium ion in cesium ion adsorption properties of zeolite and soil

The results of this experiment indicate that when zeolite is applied to soil contaminated with radiocesium, the zeolite adsorbs water-soluble cesium ion, which is easily taken up by a plant, and cesium ions that are weakly exchanged and adsorbed by negative charges of humus or clay minerals. If nitrogen and potassium fertilizers are applied before rice planting, ammonium ions and potassium ions are adsorbed by the zeolite. Although some cesium ions may be released, the release of cesium into the soil solution is deemed to be less than in soil without zeolite.

\subsubsection{Inhibition Mechanism of Radiocesium Absorption to Rice by Application of Zeolite}

The effectiveness of potassium fertilizers in inhibiting the absorption of radiocesium by crops has been reported on many occasions since the atom and hydrogen bomb tests on Bikini Atoll, the Chernobyl nuclear disaster, and the Fukushima Daiichi Nuclear Power Station accident. Ammonium ions, on the other hand, which are almost the same size and behave the same way as potassium ions in soil, are often considered as having no effect in inhibiting the absorption of radiocesium or, conversely, may even be considered as accelerating its absorption. The results of the foregoing tests conducted by the authors showed an increase in the protein content and yield of brown rice from the application of zeolite in the paddy fields and an 
accompanying reduction in the radiocesium concentration. Moreover, the results of laboratory tests on the behavior of potassium ions in soil where potassium chloride has been applied suggest that the mechanism of the zeolite effect is as follows.

Being an alkali metal, cesium behaves as a univalent cation in soil. As a result, it exists as exchangeable cesium adsorbed by the negative charges in soil colloids and water-soluble cesium dissolved in the soil solution. Compared to the cations that exist in large quantities in the soil, such as calcium, magnesium, and potassium, the specific adsorption strength (exchange invasion power) of cesium in the soil colloids is higher, and thus the proportion of water-soluble cesium is extremely low. When zeolite is applied to paddy fields contaminated with radiocesium, watersoluble radiocesium ions that have not been adsorbed by the clay minerals are adsorbed by the zeolite. As a result, the concentration of water-soluble radiocesium drops, and thus radiocesium ions that have been adsorbed by $\mathrm{pH}$-dependent charges in the humus or clay minerals separate and are adsorbed by the zeolite. Consequently, a plot where zeolite is applied has a lower concentration of radiocesium ions in the soil solution than a plot without zeolite. If ammonium and potassium ions are supplied as fertilizers, both ions behave in the same way as radiocesium ions and thus the concentration of ammonium and potassium ions in the soil solution drops. Because radiocesium ions are adsorbed more easily by the zeolite than ammonium ions and potassium ions, the ratio of $\mathrm{NH}_{4}^{+}+\mathrm{K}^{+}$to $\mathrm{Cs}^{+}$in the soil solution is higher in plots where zeolite has been applied. When the root of the rice plant extends into soil having such an ion composition, the plant will preferentially absorb ammonium and potassium ions over radiocesium ions and thus the absorption of radiocesium can be inhibited. If the concentration of both ammonium and potassium ions in the soil solution drops after being absorbed by the rice plant, those ions that have been adsorbed in the zeolite and soil will separate to maintain the ion concentration ratio at a certain level. Therefore, the absorption of radiocesium ions by the rice plant is inhibited until no more ammonium and potassium ions are left in the soil.

Paddy fields generally have a water requirement in depth of about $20 \mathrm{~mm} /$ day. Although some of the water may evaporate from the surface of the paddy fields, a proportion will permeate downward. As a result, some of the water-soluble ammonium and potassium ions applied as fertilizers will leach into the sublayers. In addition, water can flow from the paddy fields, particularly during heavy rains, and these ions may also flow out as a result. However, as the laboratory test results show, if zeolite is applied, it will adsorb both the ammonium and potassium ions, resulting in fewer water-soluble ions that can leach or flow out, thereby maintaining the inhibition of radiocesium absorption by the rice plants. In addition, application of zeolite is thought to have increased the efficiency of the nitrogen and potassium fertilizers, resulting in an increase in the protein content and yield of the brown rice.

In other words, zeolite is able to specifically adsorb cesium ions, and this specificity exceeds that for ammonium and potassium ions. However, the efficacy of zeolite in inhibiting the absorption of radiocesium by rice plants is considered to be mainly because of its ability to adsorb ammonium and potassium ions, thereby inhibiting the leaching and outflow of nitrogen and potassium from the plow layer. 
When trying to inhibit the absorption of radiocesium in paddy fields, therefore, instead of applying a large quantity of potassium fertilizers from the start, zeolite should be applied before determining the amount of potassium to use.

Zeolite can act to adsorb ammonium and potassium ions in paddy fields when used to inhibit the absorption of radiocesium in crops. In upland fields where almost no ammonium ions exist because of the formation of nitrate ion, zeolite functions by adsorption of potassium ions. The optimal amount to apply is 5-10 t/ha, or alternatively, approximately $0.2-0.3 \mathrm{t} / \mathrm{ha}$ can be applied continuously for several years. Additional applications are not needed as zeolite remains in the soil for the long term as a stable mineral.

Natural zeolite sold commercially varies in terms of production area, main mineral component (mordenite, clinoptilolite), particle size, and other factors. However, in Japan there is no need to rely on imports and artificial zeolite as the country produces a large quantity of world-class natural zeolite (with a CEC of approximately $150 \mathrm{mEq} / 100 \mathrm{~g}$ ), mainly in the Tohoku region, including Fukushima, Yamagata, Miyagi, and Akita prefectures. So long as the CEC is high, there is no difference in efficacy according to zeolite particle size or main mineral component. That said, powdered products may be cheap, but they scatter easily during application. In contrast, coarse products with a particle size of about 1-2 mm are easier to apply but are more expensive. The most efficient way to apply zeolite, therefore, is to use a lime sower to scatter a low-cost powdered product that has not been overdried, but contains approximately $20 \%$ water.

Open Access This chapter is distributed under the terms of the Creative Commons Attribution Noncommercial License, which permits any noncommercial use, distribution, and reproduction in any medium, provided the original author(s) and source are credited. 